\title{
Serum Nesfatin-1 Levels in Patients With Different Glucose Tolerance Levels
}

\author{
S. ALGUL ${ }^{1}$, Y. OZKAN ${ }^{2}$, O. OZCELIK ${ }^{1}$ \\ ${ }^{1}$ Department of Physiology, Faculty of Medicine, Firat University, Elazig, Turkey, ${ }^{2}$ Department of \\ Internal Medicine, Section of Endocrinology and Metabolic Disease, Faculty of Medicine, Frrat \\ University, Elazig, Turkey
}

Received September 11, 2015

Accepted April 15, 2016

On-line August 19, 2016

\section{Summary}

The aim of this study was to compare the levels of nesfatin- 1 in healthy subjects with those in prediabetic and diabetic patients who have different glucose tolerance levels. Overall, 100 subjects were divided into 5 groups healthy control (C), impaired fasting glycemia (IFG), impaired glucose tolerance (IGT), metabolic syndrome (MS) and type 2 diabetes mellitus, (Type 2 DM). Glycated hemoglobin (HbA1c) assessed the glycemic control. Homeostasis model assessment of insulin resistance (HOMA-IR) was determined using computer analyses. Nesfatin-1 levels were measured using ELISA method. IFG and IGT (prediabetic groups) from MS and Type 2 DM (diabetic groups) differed significantly in HOMA-IR. The nesfatin-1 levels were lower, although not statistically significant, in IFG $(0.937 \pm 0.03 \mathrm{ng} / \mathrm{ml}, \mathrm{p}=0.07)$ and IGT $(1.039 \pm 0.06 \mathrm{ng} / \mathrm{ml}, \mathrm{p}=0.5)$ groups compared to healthy subjects $(1.094 \pm 0.07 \mathrm{ng} / \mathrm{ml})$. However, the nesfatin-1 levels were lower in patients with Type $2 \mathrm{DM}(0.867 \pm 0.02 \mathrm{ng} / \mathrm{ml}$, $\mathrm{p}=0.007)$ and $\mathrm{MS}(0.885 \pm 0.01 \mathrm{ng} / \mathrm{ml}, \mathrm{p}=0.01)$ compared to healthy subjects. Nesfatin-1 levels were significantly lower in diabetic patients compared to healthy subjects. This study supports the role of insulin resistance in decreased nesfatin-1 levels in patients with Type 2 DM and MS.

\section{Key words}

Type 2 diabetes mellitus - Impaired glucose regulation • Nesfatin-1 • Insulin

\section{Corresponding author}

O. Ozcelik, Department of Physiology, Faculty of Medicine, Firat University, Elazig, Turkey. Fax: +90 424237 9138. E-mail: oozcelik@excite.com or oozcelik@firat.edu.tr

\section{Introduction}

It is well known that nesfatin-1 has important effects on food intake (anorexigenic effects) and regulation of energy homeostasis through mechanism(s) independent of leptin (Oh-I et al. 2006, Kohno et al. 2008, Stengel and Taché 2014). Recent data has also revealed regulatory role of nesfatin-1 in glucose homeostasis which is antihyperglycemic ( $\mathrm{Su}$ et al. 2010, Nakata et al. 2011). The detection of nesfatin-1 located in beta cell containing insulin could provide an evidence of its connection with glucose metabolism (Stengel et al. 2009, Goebel et al. 2009, Foo et al. 2010).

However, the mechanism of action through which nesfatin-1 regulates glucose metabolism is not clear yet. Type 2 diabetes mellitus (Type 2 DM) is typically associated with an altered glucose metabolism, insulin resistance, abnormal fasting glucose levels, and impaired glucose tolerance. In addition, prediabetes (impaired glucose regulation), which World Health Organisation defines as impaired fasting glycemia (IFG) and impaired glucose tolerance (IGT), also serious impairs glucose metabolism (Waugh et al. 2007). The studies in literature on the relationships between diabetes and nesfatin-1 have revealed conflicting results. Some studies have shown a low nesfatin-1 levels in patient with Type 2 DM and high nesfatin-1 levels in patients with Type 1 DM (Li et al. 2010). However, the other studies have observed high nesfatin-1 levels in patients with Type 2 DM and patients with IGT (Zhang et al. 2012).

To our knowledge, no extensive studies have 
been conducted in patients with different glucose metabolic impairment and nesfatin-1 levels. It is important to understand whether nesfatin-1 can be used as a supportive tool in the diagnosis and treatment of glucose metabolic impairments.

In the present study, we comparatively examined the nesfatin-1 levels in patients with IFG, IGT, Type 2 DM, metabolic syndrome (MS) and healthy subjects.

\section{Materials and Methods}

\section{Subjects}

This study included 100 participants: 80 patients (38 males; 42 females) with different impaired glucose tolerance (who attended Diabetes, Endocrine, and Metabolism Unit at Frrat University Hospital) and 20 healthy subjects.

The subjects were divided into 5 different groups: 20 healthy subjects comprised the control group (C group 1, age 39.2 \pm 1.2 years, height $168 \pm 1 \mathrm{~cm}$, weight $68.0 \pm 2.2 \mathrm{~kg}$, body mass index (BMI) $24.1 \pm 0.7 \mathrm{~kg} / \mathrm{m}^{2}$ ), 20 patients with impaired fasting glycemia (IFG group 2, age $42.3 \pm 1.2$ years, height $162 \pm 2 \mathrm{~cm}$, weight $81.7 \pm$ $5.1 \mathrm{~kg}$, BMI $31.1 \pm 2.1 \mathrm{~kg} / \mathrm{m}^{2}$ ), 20 patients with impaired glucose tolerance (IGT group 3: age $41.8 \pm 1.3$ years, height $163 \pm 2 \mathrm{~cm}$, weight $75.8 \pm 4.2 \mathrm{~kg}$, BMI $28.6 \pm$ $1.6 \mathrm{~kg} / \mathrm{m}^{2}$ ), 20 patients with metabolic syndrome (MS group 4, age $38.5 \pm 1.4$ years, height $166 \pm 1 \mathrm{~cm}$, weight $84.3 \pm 3.1 \mathrm{~kg}$, BMI $30.7 \pm 1.4 \mathrm{~kg} / \mathrm{m}^{2}$ ), and 20 patients with type 2 diabetes mellitus (Type $2 \mathrm{DM}$ group 5 , age $40.6 \pm 1.4$ years, height $164 \pm 2 \mathrm{~cm}$, weight $79.4 \pm$ $2.3 \mathrm{~kg}$, BMI $29.6 \pm 0.8 \mathrm{~kg} / \mathrm{m}^{2}$ ).

The diagnoses of Type 2 DM, IFG, and IGT were made according to the American Diabetes Association criteria. IFG is defined by the fasting glucose level $\geq 100$ and $<126 \mathrm{mg} / \mathrm{dl}$ (Genuth et al. 2003). IGT is defined by an elevated 2 -h glucose level $\geq 140$ and $<200 \mathrm{mg} / \mathrm{dl}$ after a 75 -g glucose load on the oral glucose tolerance test in the presence of a fasting glucose level $<126 \mathrm{mg} / \mathrm{dl}$ (Genuth et al. 2003). MS was identified using the Adult Treatment Panel III report (ATP III) and the group MS included only patients with Type 2 DM (Grundy et al. 2004).

Before participating in the study, all patients and control subjects underwent physical examination and laboratory evaluation including lipid parameters, thyroid function tests, and serum cortisol measurement for probable endocrine pathology (Liu et al. 2014).

The subjects in control group had a normal glucose tolerance (no diabetes history, endocrine disorders, and any medications). Clinical exclusion criteria included Type $1 \mathrm{DM}$, gestational DM, pregnancy, hormone replacement therapy, major depressive disorders and cancer, a history of drug use (systemic glucocorticoids and antipsychotics), thyroid and other endocrine disorders, severe acute or chronic infectious disease, systemic diseases (heart failure, liver or kidney disease, or lung disease).

All procedures were conducted in accordance with The Code of Ethics of the World Medical Association (Declaration of Helsinki) for experiments involving humans. The Frrat University Local Ethic Committee approved the study protocol, and informed written consent was obtained from each subject before the study.

\section{Biochemical parameters and hormone analyses}

Blood samples $(5 \mathrm{ml})$ were drawn from a forearm vein in the morning after overnight fasting for hormone and other biochemical analyses. All samples were placed into aprotinin or EDTA containing tubes until centrifugation at $4500 \mathrm{rpm}$ for $5 \mathrm{~min}$ at $4{ }^{\circ} \mathrm{C}$. The separated serum and plasma were stored at $-80{ }^{\circ} \mathrm{C}$ and analyzed immediately at the end of study (Hettich, Zentrifugen Universal $32 \mathrm{R}$, Germany). Samples from each subject were analyzed in the same assay.

Fasting serum nesfatin-1 levels were measured using a commercial enzyme-linked immunosorbent assay (ELISA) kit (Phoenix Pharmaceuticals, Belmont, CA, USA). The linear range of the assay was $0.78 \mathrm{ng} / \mathrm{ml}$. The inter-assay and the intra-assay coefficients of variation were $10 \%$ and $15 \%$, respectively.

Plasma insulin level was measured according to the electrochemiluminescence immunoassay method using an automated immunoassay analyzer (Immulite 2500 Insulin, Diagnostic Products Corporation, Los Angeles, CA, USA). Serum glucose, total cholesterol, very low density lipoprotein (VLDL), high density lipoprotein (HDL), and low density lipoprotein (LDL) cholesterol levels were determined using commercial kits in Olympus AU600 autoanalyzer.

The glycemic control of the patients was assessed by glycated hemoglobin (HbAlc) (i.e. the mean plasma glucose level over the preceding 2 to 3 months). HbA1c levels were detected by autoanalyzer from EDTA containing blood samples. Homeostasis model assessment of insulin resistance (HOMA-IR) was determined using computer analyses (i.e. fasting blood glucose and insulin levels). 
Statistical analyses

Power analysis was used to determine the number of subjects in each group. Values are expressed mean \pm standard error. The Kolmogorov-Smirnov $\mathrm{Z}$ test showed that the data were normally distributed and thus using parameters test was justified. One way ANOVA was used to determine between group differences, and Pearson correlation analysis was used to evaluate the relationship between observed values with $\mathrm{p}<0.05$ being accepted as significant statistically.

\section{Results}

The biochemical results among study groups are given in Table 1. No significant correlation was detected among the nesfatin-1 levels, lipid parameters (including, VLDL, LDL and HDL), and BMI in any of the study groups. The insulin levels were significantly higher in patients groups compared with the control group. In addition, insulin levels were significantly different in diabetic groups (MS and Type $2 \mathrm{DM}$ ) compared to prediabetic groups (IFG and IGT) $(\mathrm{p}=0.001)$ (Table 1).

Table 1. The clinical characteristics of the study groups. Fasting blood glucose $\left(B G_{F}\right)$, postprandial blood glucose (BGPB), fasting insulin, low-density lipoprotein (LDL), very low density lipoprotein (VLDL) high-density lipoprotein (HDL).

\begin{tabular}{|c|c|c|c|c|c|c|}
\hline & $\begin{array}{c}\mathbf{B G}_{\mathrm{F}} \\
(\mathrm{mg} / \mathrm{dl})\end{array}$ & $\begin{array}{l}\mathbf{B G}_{\mathrm{PB}} \\
(\mathrm{mg} / \mathrm{dl})\end{array}$ & $\begin{array}{l}\text { Insulin } \\
\text { (ulU/ml) }\end{array}$ & $\begin{array}{c}\text { LDL } \\
\text { (mg/dl) }\end{array}$ & $\begin{array}{l}\text { VLDL } \\
\text { (mg/dl) }\end{array}$ & $\begin{array}{c}\text { HDL } \\
(\mathrm{mg} / \mathrm{dl})\end{array}$ \\
\hline Control & $91 \pm 1$ & $123 \pm 2$ & $4.86 \pm 0.8$ & $73 \pm 3$ & $18 \pm 1$ & $62 \pm 2$ \\
\hline$I F G$ & $111 \pm 1 *$ & $128 \pm 2 *$ & $7.00 \pm 0.6^{*}$ & $110 \pm 6^{*}$ & $29 \pm 3 *$ & $45 \pm 1 *$ \\
\hline$I G T$ & $116 \pm 1^{*}$ & $186 \pm 2 *$ & $7.74 \pm 0.6^{*}$ & $133 \pm 8^{*}$ & $38 \pm 3 *$ & $48 \pm 1 *$ \\
\hline$M S$ & $124 \pm 5^{*}$ & $174 \pm 8^{*}$ & $9.92 \pm 0.9^{*}+$ & $120 \pm 5^{*}$ & $48 \pm 3^{*}$ & $39 \pm 1^{*}$ \\
\hline Type 2 DM & $234 \pm 11^{*}$ & $321 \pm 20^{*}$ & $10.14 \pm 0.9 * \dagger$ & $137 \pm 4 *$ & $47 \pm 5^{*}$ & $36 \pm 1^{*}$ \\
\hline
\end{tabular}

Values are presented as mean \pm SEM. $*$ indicates significant differences compared to the control $(p<0.05) . \neq$ indicates significant differences compared to the IFG and IGT $(p<0.05)$.

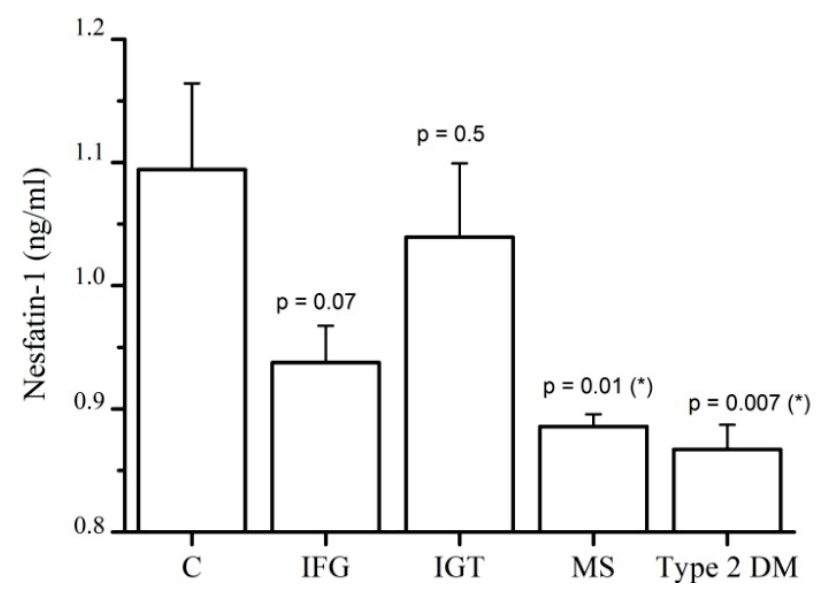

Fig. 1. Nesfatin-1 levels in response to the control (C), impaired fasting glycemia (IFG), impaired glucose tolerance (IGT), metabolic syndrome (MS), and Type 2 DM groups. Values are presented as mean \pm SE. * indicates significant differences compared to the control levels.

The serum nesfatin-1 levels in healthy subjects and patients with IFG, IGT, MS, and Type 2 DM are presented in Figure 1. The nesfatin-1 levels for control group were $1.094 \pm 0.07 \mathrm{ng} / \mathrm{ml}$. Although it was lower in patients with IFG $(0.937 \pm 0.03 \mathrm{ng} / \mathrm{ml})$ and IGT
$(1.039 \pm 0.06 \mathrm{ng} / \mathrm{ml})$, the differences in nesfatin-1 levels between control and two prediabetic groups were not significant $(\mathrm{p}=0.07$ and $\mathrm{p}=0.5$, respectively) (Fig. 1). However, we observed statistically significant lower nesfatin-1 levels in patients with Type $2 \mathrm{DM}(0.867 \pm 0.02$ $\mathrm{ng} / \mathrm{ml})(\mathrm{p}=0.007)$ and $\mathrm{MS}(0.885 \pm 0.01 \mathrm{ng} / \mathrm{ml})(\mathrm{p}=0.01)$, compared to the control group (Fig. 1).

The HOMA-IR (units) (Fig. 2) and HbA1c (\%) (Fig. 3) levels were significantly higher in patients with IFG (1.916 \pm 0.19 units, $\mathrm{p}<0.0001 ; \quad 5.40 \pm 0.11 \%$, $\mathrm{p}<0.0001), \quad$ IGT $\quad(2.164 \pm 0.17 \quad$ units, $\mathrm{p}<0.0001$; $6.37 \pm 0.12 \%, \quad \mathrm{p}<0.0001), \quad \mathrm{MS} \quad(3.084 \pm 0.35$ units, $\mathrm{p}<0.0001 ; 5.90 \pm 0.15 \%, \mathrm{p}<0.0001)$ and Type $2 \mathrm{DM}$ (6.694 \pm 0.53 units, $\mathrm{p}<0.0001 ; 9.11 \pm 0.32 \%, \mathrm{p}<0.0001)$ compared to the control group $(1.057 \pm 0.17$ units; $4.87 \pm 0.08 \%$ ), respectively. The HOMA-IR levels were significantly different between prediabetic (IFG and IGT) and diabetic (Type $2 \mathrm{DM}$ and MS with Type $2 \mathrm{DM}$ ) groups: IGT vs. MS, $\mathrm{p}=0.02$; IGT vs. Type $2 \mathrm{DM}$, $\mathrm{p}<0.0001$; IFG vs. MS, $\mathrm{p}=0.006$; IFG vs. Type $2 \mathrm{DM}$, $\mathrm{p}<0.0001$. However, no significant differences were observed in HOMA-IR levels between IFG and IGT groups $(\mathrm{p}=0.3)$. 


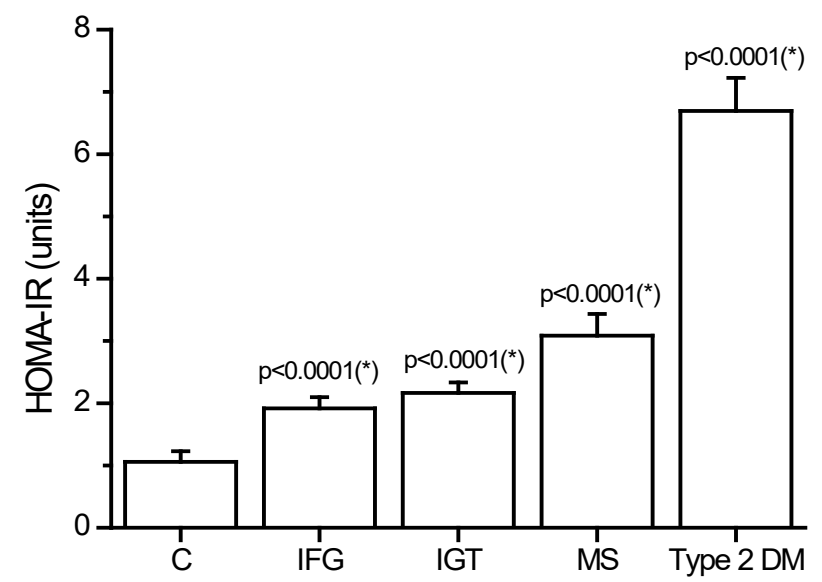

Fig. 2. HOMA-IR in response to the control (C), impaired fasting glycemia (IFG), impaired glucose tolerance (IGT), metabolic syndrome (MS), and Type 2 DM groups. Values are presented as mean $\pm \mathrm{SE} . *$ indicates significant differences compared to the control levels.

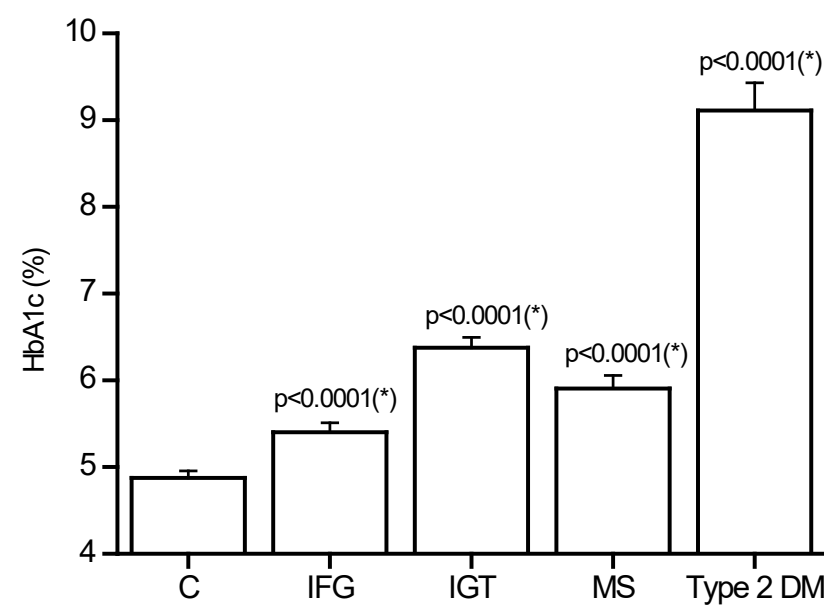

Fig. 3. HbA1c in response to the control (C), impaired fasting glycemia (IFG), impaired glucose tolerance (IGT), metabolic syndrome (MS), and Type 2 DM groups. Values are presented as mean $\pm \mathrm{SE} . *$ indicates significant differences compared to the control levels.

\section{Discussion}

The results of previous studies revealed that nesfatin-1 is becoming a vitally important peptide hormone for obesity (by effect on body energy metabolism), diabetes (effect involving glucose metabolism) (Masuo 2014), and mental-depressive disorders (Algul et al. 2013). In the present study, we compared nesfatin-1 levels in prediabetic and diabetic patients, including four different impaired glucose metabolisms, as determined by HOMA-IR. We determined that nesfatin-1 levels were slightly but not significantly lower in patients with IFG and IGT (prediabetic patients) compared to healthy subjects
(Fig. 1). However, nesfatin-1 levels were significantly lower in patients with Type 2 DM and MS compared to healthy subjects. It is important to clarify the response of nesfatin-1 at different levels of impaired glucose metabolism.

The finding indicating low nesfatin-1 levels in Type 2 DM (Li et al. 2010, Liu et al. 2014) and MS (Aksu et al. 2015) is associated with the findings of some previous studies. However, our finding was not in agreement with previous findings that have shown elevated nesfatin-1 levels in patients with Type 2 DM (Zhang et al. 2012) and patients with IGT (Guo et al. 2013). HOMA-IR was found to be significantly higher in diabetic groups with highly impaired glucose metabolism compared to control. Interestingly, it has been suggested that low nesfatin-1 levels of diabetic patients could be one of the stimulating factors in diabetic hyperphagia (Li et al. 2010). Thus, nesfatin-1 has a reducing effects on food intake, i.e. it acts as a potential anorexigenic agent (Oh-I et al. 2006, Li et al. 2010).

Importantly, we have also found significant differences $(p<0.05)$ in insulin resistance between diabetic (MS and Type 2 DM), and prediabetic (IFG and IGT) groups, as determined by HOMA-IR. Thus, insulin resistance and impaired insulin secretion could possibly explain for the significantly lower nesfatin-1 levels in diabetic group (Taylor et al. 1994). Distribution of fat mass in patients with MS may be the reason for the high insulin resistance (Grundy 2006). Several observations have indicated that nesfatin-1 affects glucose metabolism by increasing insulin sensitivity (Gonzalez et al. 2011, Li et al. 2013). Different insulin resistance mechanisms are involved in IFG (predominantly hepatic insulin resistance and normal muscle insulin sensitivity) and IGT (slightly reduced hepatic insulin sensitivity and moderate to severe muscle insulin resistance) (Abdul-Ghani et al. 2006). Insulin treatment or improvement of blood glucose might play a role in the changes in nesfatin- 1 in diabetic patients (Gonzalez et al. 2009).

The relationships between nesfatin-1 with body weight and insulin resistance in obese subjects have been shown (Anwar et al. 2014). In the present study, we did not find any correlation between nesfatin-1 levels and body weight or insulin resistance in any of the study groups. We observed significantly low nesfatin-1 levels in Type $2 \mathrm{DM}$ and MS group compared to control group. The results of previous studies revealed significantly higher levels of serum nesfatin-1 in obese individuals than in control subjects (Anwar et al. 2014). In addition, 
low nesfatin-1 levels have been reported in patients with anorexia nervosa (Ogiso et al. 2011). A significantly positive correlation between BMI and nesfatin-1 levels in obese individuals has been shown (Ramanjaneya et al. 2010), although a negative correlation has also been reported in non-obese subjects (Tsuchiya et al. 2010). In contrary, patients with insulin resistance had statistically insignificant lower nesfatin-1 levels compared to obese children without insulin resistance (Abaci et al. 2013). A recent study has shown that the insulin producing beta cells colocalized prepronesfatin in the islets of both mice and rats, suggesting a potential role of prepronesfatin-derived peptides in insulin secretion and glucose metabolism (Gonzalez et al. 2009).

Our study was limited by its cross-sectional design and, a relatively small sample size; therefore it cannot prove a causal relationship between altered nesfatin-1 levels and the development of Type 2 DM. Other important point to be emphasized is that all patients were not newly diagnosed, and some of them had already been getting therapy. Baseline characteristics of prediabetic, diabetic and control groups were not comparable, which may have had an effect on the conclusion. Future studies concerning the nesfatin-1 levels in response to the diabetic therapy, including the effects of oral antidiabetic and insulin treatment, is needed. Establishing the biochemical and physiological effects of nesfatin-1 on the regulatory mechanisms of body energy systems will contribute to clarify the factors that might contribute to glucose metabolism impairment.

\section{Conclusion}

The novelty of our study is that we showed, for the first time, significantly lower nesfatin-1 levels in diabetic patients (Type $2 \mathrm{DM}$ and MS) but not in prediabetic patients (IGT and IFG). Nesfatin-1 is a newly identified polypeptide probably involved, inter alia, in the regulation of food intake. It is important to clarify the relationships between nesfatin-1 and insulin resistance with regard to diabetes. To elucidate its physiological role further studies are required.

\section{Conflict of Interest}

There is no conflict of interest.

\section{References}

ABACI A, CATLI G, ANIK A, KUME T, BOBER E: The relation of serum nesfatin-1 level with metabolic and clinical parameters in obese and healthy children. Pediatr Diabetes 14: 189-195, 2013.

ABDUL-GHANI MA, TRIPATHY D, DEFRONZO RA: Contributions of $\beta$-cell dysfunction and insulin resistance to the pathogenesis of impaired glucose tolerance and impaired fasting glucose. Diabetes Care 29: 1130-1139, 2006.

AKSU O, AYDIN B, DOGUC DK, ILHAN I, OZTURK O, ALTUNTAS A, DEMIRKAN H, KOROGLU BK, TAMER MN: The evaluation of nesfatin-1 levels in patients with OSAS associated with metabolic syndrome. J Endocrinol Invest 38: 463-469, 2015.

ALGUL S, ERMAN F, KARA B, KARA M, ERMAN O: The effect of short-term antidepressant treatment on serum levels of nesfatin-1, nitric oxide and ghrelin in patients with major depressive disorder. F U Med J Health Sci 27: 69-73, 2013.

ANWAR GM, YAMAMAH G, IBRAHIM A, EL-LEBEDY D, FARID TM, MAHMOUD R: Nesfatin-1 in childhood and adolescent obesity and its association with food intake, body composition and insulin resistance. Regul Pept 188: 21-24, 2014.

FOO KS, BRAUNER H, OSTENSON CG, BROBERGER C: Nucleobindin-2/nesfatin in the endocrine pancreas: distribution and relationship to glycaemic state. J Endocrinol 204: 255-263, 2010.

GENUTH S, ALBERTI KG, BENNETT P, BUSE J, DEFRONZO R, HAHN R, KITZMILLER J, KNOWLER WC, LEBOVITZ H, LERNMARK A, NATHAN D, PALMER J, RIZZA R, SAUDEK C, SHAW J, STEFFES M, STERN M, TUOMILEHTO J, ZIMMET P; EXPERT COMMITTEE ON THE DIAGNOSIS AND CLASSIFICATION OF DIABETES MELLITUS: Follow-up report on the diagnosis of diabetes mellitus. Diabetes Care 26: 3160-3167, 2003.

GRUNDY SM: Atherogenic dyslipidemia associated with metabolic syndrome and insulin resistance. Clin Cornerstone 8 (Suppl 1): S21-S27, 2006. 
GRUNDY SM, BREWER HB JR, CLEEMAN JI, SMITH SC JR, LENFANT C; AMERICAN HEART ASSOCIATION, NATIONAL HEART, LUNG, BLOOD INSTITUTE: Definition of metabolic syndrome: Report of the National Heart, Lung, and Blood Institute/American Heart Association conference on scientific issues related to definition. Circulation 109: 433-438, 2004.

GOEBEL M, STENGEL A, WANG L, LAMBRECHT NW, TACHÉ Y: Nesfatin-1 immunoreactivity in rat brain and spinal cord autonomic nuclei. Neurosci Lett 452: 241-246, 2009.

GONZALEZ R, TIWARI A, UNNIAPPAN S: Pancreatic beta cells colocalize insulin and pronesfatin immunoreactivity in rodents. Biochem Biophys Res Commun 381: 643-648, 2009.

GONZALEZ R, PERRY RL, GAO X, GAIDHU MP, TSUSHIMA RG, CEDDIA RB, UNNIAPPAN S: Nutrient responsive nesfatin-1 regulates energy balance and induces glucose-stimulated insulin secretion in rats. Endocrinology 152: 3628-3637, 2011.

GUO Y, LIAO Y, FANG G, DONG J, LI Z: Increased nucleobindin (NUCB2) transcriptional activity links the regulation of insulin sensitivity in Type 2 diabetes mellitus. J Endocrinol Invest 36: 883-888, 2013.

KOHNO D, NAKATA M, MAEJIMA Y, SHIMIZU H, SEDBAZAR U, YOSHIDA N, DEZAKI K, ONAKA T, MORI M, YADA T: Nesfatin-1 neurons in paraventricular and supraoptic nuclei of the rat hypothalamus coexpress oxytocin and vasopressin and are activated by refeeding. Endocrinology 149: 1295-1301, 2008.

LI QC, WANG HY, CHEN X, GUAN HZ, JIANG ZY: Fasting plasma levels of nesfatin-1 in patients with type 1 and type 2 diabetes mellitus and the nutrient related fluctuation of nesfatin-1 level in normal humans. Regul Pept 159: 72-77, 2010.

LI Z, GAO L, TANG H, YIN Y, XIANG X, LI Y, ZHAO J, MULHOLLAND M, ZHANG W: Peripheral effects of nesfatin-1 on glucose homeostasis: PLoS One 8: 71513, 2013.

LIU F, YANG Q, GAO N, LIU F, CHEN S: Decreased plasma nesfatin-1 level is related to the thyroid dysfunction in patients with type 2 diabetes mellitus. J Diabetes Res 2014: 128014, 2014.

MASUO K: Nesfatin-1 could be a strong candidate obesity or diabetes medication, if blood pressure elevation can be controlled. Hypertens Res 37: 98-99, 2014.

NAKATA M, MANAKA K, YAMAMOTO S, MORI M, YADA T: Nesfatin-1 enhances glucose-induced insulin secretion by promoting $\mathrm{Ca}(2+)$ influx through L-type channels in mouse islet $\beta$-cells. Endocr J 58: 305-313, 2011.

OGISO K, ASAKAWA A, AMITANI H, NAKAHARA T, USHIKAI M, HARUTA I, KOYAMA K, AMITANI M, HARADA T, YASUHARA D, INUI A: Plasma nesfatin-1 concentrations in restricting-type anorexia nervosa. Peptides 32: 150-153, 2011.

OH-I S, SHIMIZU H, SATOH T, OKADAS, ADACHI S, INOUE K, EGUCHI H, YAMAMOTO M, IMAKI T, HASHIMOTO K, TSUCHIYA T, MONDEN T, HORIGUCHI K, YAMADA M, MORI M: Identification of nesfatin-1 as a satiety molecule in the hypothalamus. Nature 443: 709-712, 2006.

RAMANJANEYA M, CHEN J, BROWN JE, TRIPATHI G, HALLSCHMID M, PATEL S, KERN W, HILLHOUSE EW, LEHNERT H, TAN BK, RANDEVA HS: Identification of nesfatin-1 in human and murine adipose tissue: a novel depot-specific adipokine with increased levels in obesity. Endocrinology 151: 3169-3180, 2010.

STENGEL A, TACHÉ Y: Brain peptides and the modulation of postoperative gastric ileus. Curr Opin Pharmacol 19: 31-37, 2014.

STENGEL A, GOEBEL M, YAKUBOV I, WANG L, WITCHER D, COSKUN T, TACHÉ Y, SACHS G, LAMBRECHT NW: Identification and characterization of nesfatin-1 immunoreactivity in endocrine cell types of the rat gastricoxyntic mucosa. Endocrinology 150: 232-238, 2009.

SU Y, ZHANG J, TANG Y, BI F, LIU JN: The novel function of nesfatin-1: anti-hyperglycemia. Biochem Biophys Res Commun 391: 1039-1042, 2010.

TAYLOR SI, ACCILI D, IMAI Y: Insulin resistance or insulin deficiency. Which is the primary cause of NIDDM? Diabetes 43: 735-740, 1994.

TSUCHIYA T, SHIMIZU H, YAMADA M, OSAKI A, OH-I S, ARIYAMA Y, TAKAHASHI H, OKADA S, HASHIMOTO K, SATOH T, KOJIMA M, MORI M: Fasting concentrations of nesfatin-1 are negatively correlated with body mass index in non-obese males. Clin Endocrinol (Oxford) 73: 484-490, 2010. 
WAUGH N, SCOTLAND G, MCNAMEE P, GILLETT M, BRENNAN A, GOYDER E, WILLIAMS R, JOHN A: Screening for type 2 diabetes: literature review and economic modelling. Health Technol Assess 11: 1-125, 2007.

ZHANG Z, LI L, YANG M, LIU H, BODEN G, YANG G: Increased plasma levels of nesfatin-1 in patients with newly diagnosed type 2 diabetes mellitus. Exp Clin Endocrinol Diabetes 120: 91-95, 2012. 